
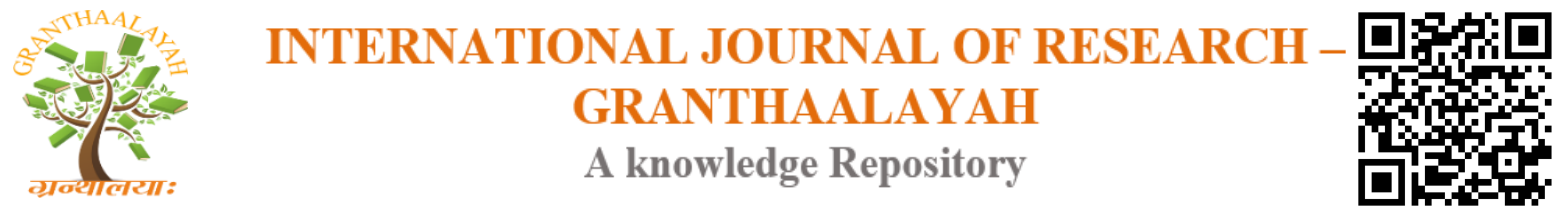

Social

\title{
IMPLEMENTATION OF THE POLICIES ON STUDENT AFFAIRS AND SERVICES AMONG STATE UNIVERSITIES AND COLLEGES IN THE ISLAND OF SAMAR: FOR PROGRAM ENHANCEMENT
}

\author{
Ronaldo A. Amit *1 \\ ${ }^{* 1}$ University of Eastern Philippines, Catarman, Northern Samar, Philippines 6400
}

\begin{abstract}
This study assessed the status of implementation of the policies on student affairs and services among state universities in the Island of Samar, as basis for program enhancement. This determined the status of implementation of the following student welfare programs and services, vis-à-vis the policies of SUC's in Samar Island with respect to admission, career and placement service, economic enterprise development, food services, guidance and counseling, health services, information and orientation service, international student service, research, monitoring and evaluation of student affairs and services, safety and security, scholarship and financial assistance, services of students with special needs, student discipline, student handbook and student housing. The four (4) SUC's in Samar Island were selected as the locale of this study. These were the University of Eastern Philippines Main Campus (Catarman), North West Samar State University Main Campus (Calbayog City), Samar State University Main Campus (Catbalogan City) and Eastern Samar State University Main Campus (Borongan City) with the university presidents, deans/directors of the Student Affairs and Services, personnel, and students as respondents. Frequency counts, percentages, and weighted mean computations were used to analyze the descriptive data obtained from the respondents of the study who were chosen through complete enumeration for presidents, deans/directors and personnel and random sampling for the students, respectively. The status of implementation of the student welfare programs and services as well as student development program and services in different state universities in the Samar Island, were both rated as "very satisfactory" which means that these programs and services were much implemented. Hence, an action plan was prepared for further enhancement of the student affairs and services in state universities as an offshoot of this study.
\end{abstract}

Keywords: Implementation; Student Affairs and Services.

Cite This Article: Ronaldo A. Amit. (2019). "IMPLEMENTATION OF THE POLICIES ON STUDENT AFFAIRS AND SERVICES AMONG STATE UNIVERSITIES AND COLLEGES IN THE ISLAND OF SAMAR: FOR PROGRAM ENHANCEMENT." International Journal of Research - Granthaalayah, 7(3), 136-141. 10.29121/granthaalayah.v7.i3.2019.953. 


\section{Introduction}

Education is a fundamental right of every citizen. Its ultimate goal is the total development of an individual - his/her physical, intellectual, emotional, social, and moral dimensions. It is an avenue through which full development of human potential and respect for human rights can be achieved.

The Congressional Commission aims to make education a tool for attaining the goals of social justice, unity, freedom, and prosperity. Education should produce a Filipino who respects his/her whole personal discipline, guided by spiritual and moral values, thinks critically and creatively, exercises responsibly his/her rights and duties as a citizen, whose mind is informed by scienctific reasons, and whose nationalism is based on a knowledge of history and cultural heritage.

Higher education is in the throes of major transformation. Forcing the transformation are economic conditions, eroding public confidence, accountability demands, and demographic shifts resulting in increased number of people from historically underrepresented groups going to college. More people are participating in higher education than ever before, yet the resources supporting the enterprise are not keeping pace with the demand. Because of these and other factors, legislators, parents, governing boards, and students want colleges and universities to reemphasize student learning and personal development as the primary goals of undergraduate education. In short, people want to know that higher education is preparing students to lead productive lives after college, including the ability to deal effectively with such major societal challenges such as poverty, illiteracy, crime, environmental exploitation, and many others.

Both the individual and institutional environments contribute to what students gain from college. Thus, the key to enhancing learning and personal development is not simply for faculty to teach more and better, but also to create conditions that motivate and inspire students to devote time and energy to educationally-purposeful activities, inside and outside the classroom. The recent focus on institutional productivity is a clarion call to re-examine the philosophical tenets that guide the professional practice of student affairs and to form partnerships with students, faculty, academic administrators, and others to help all students attain high levels of learning and personal development.

The student services endeavor to assist students obtain the optimum desired development in their environment. The function of the Office of Student Affairs is to contribute to the personal development of the individual as a fundamental role of an organized education.

Limited provisions along student services other than the formal classroom teaching may hamper the efficiency and effectiveness of the teaching-learning process. Student services to be truly supportive of the entire school program should be systematically operated to ensure the required assistance to the students in enhancing their best judgment to problems and situations they may encounter towards optimization of their potential.

In addition, there is an increasing evidence that higher education must also address the basic personal needs of students by possibly providing a comprehensive package of out-of-classroom student services and programs, commonly referred to as student affairs and services. These efforts should be designed to enable and empower students to focus more intensely on their studies and their personal growth and maturity, both cognitively and emotionally, with enhanced student 
learning outcomes. Furthermore, another important concern under consideration of this undertaking is economy. By and large, investment in students and student affairs and services provide a healthy return of investment to national economy giving assurance to students' success in higher education and their subsequent contributions to the national interest.

\section{Methodology}

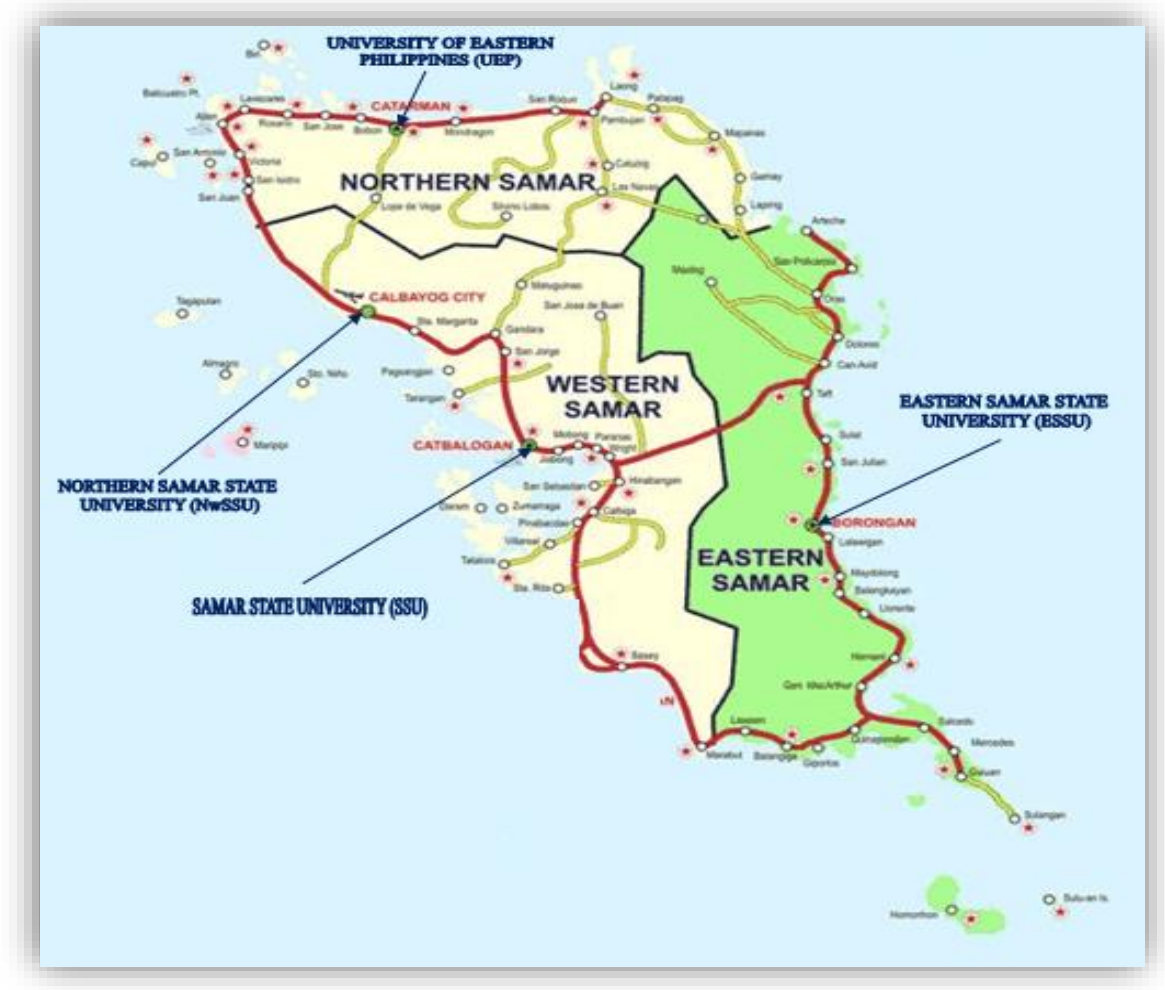

Figure 1: Administrative map of Samar Island showing the location of sampled universities

To assess the status of implementation of the policies on student affairs and services among state universities in Samar Island, as basis for program enhancement, the descriptive-evaluative method of research was utilized in this study. The descriptive data were obtained from the respondents who were chosen through complete enumeration for presidents, deans/directors and personnel and random sampling for the students, respectively. This study was conducted in state universities that are situated in Samar Island, namely: the University of Eastern Philippines Main Campus (Catarman), North West Samar State University Main Campus (Calbayog City), Samar State University Main Campus (Catbalogan City) and Eastern Samar State University Main Campus (Borongan City).

\section{Results and Discussion}

As to the level of awareness on the existence and implementation of student programs and services, all the SUC presidents, deans of the Office of the Student Affairs, personnel and students were much aware of the existence, the vision, mission, and goals of the different student programs and services. 
Concerning the degree of responsiveness as to the students' affairs and services, the respondents rated eleven (11) indicators as much responsive: extending assistance and showing deep concern to the students; working hard to fulfill the unit's mission and to attain institutional goals; maintaining harmonious working relations with co-workers and other school personnel; exerting continuous effort to ensure improved services; managing the office smoothly with ease and confidence; exercising professionalism in confronting issues and problems solving; is knowledgeable of the nature of the job and discharges functions promptly; observing proper utilization with the time and efficient use of supplies and materials; coordinating and establishing linkages with other units and offices for the provision of services other than what s/he can offer; extending duty and performing job even beyond the required time without additional compensation; and identifying himself/herself with his/her unit with pride.

As to the status of implementation of the student welfare programs and services in different state universities in Samar Islands, the respondents indicated "very satisfactory" on the different programs and services such as admission, career and placement service, economic enterprise development, food services, guidance and counseling, health services, information and orientation service, international student service, research, monitoring and evaluation of student affairs and services, safety and security, scholarship and financial assistance, services of students with special needs, student discipline, student handbook development, and student housing.

As to status of implementation of the students' development programs and services, the respondents also rated the following programs and services as "very satisfactory": cultural development program, leadership training program, multi-faith services, social and community development program, sports development program, student organization and services, student publications, and student/council government.

On the test of difference, it showed that there were significant differences in the responses/views of the SUC presidents, deans/directors of Student Affairs and Services, personnel and students on the status of the implementation of student welfare program and services and student development program and services in the SUC's in the Island of Samar.

Also, on the test of difference on the degree of responsiveness of the respondents from the different SUC's surveyed, it showed that there was no significant differences.

Regarding the problems encountered in the implementation of the student affairs programs and services, a greater number perceived that there was an insufficient budget allocation given for the implementation of the students' welfare and development programs and services.

\section{Conclusion}

The SUC presidents, deans/directors, personnel, and students are much aware of the existence and implementation, vision, mission, and goals of student programs and services of the Office of the Student Affairs. This implies that the respondents are fully aware of the Student Affairs programs and services. 
The SUC presidents, deans/directors, personnel, and students are much responsive to the students' affairs and services. This implies that the Student Affairs and Services under study are very much responsive to the student affairs and services which means that the respondents have the same responses and that the main thrust of the institution is well delivered to its clientele.

That the status of implementation of the student welfare programs and services in different state universities in Samar Island is rated very satisfactory. This implies that the services and programs provided by the Office of the Student Affairs ensure and promote the students' well-being which also means that the institution is implementing well its programs and services.

Moreover, on the test of difference on the degree of responsiveness of the respondents on the student affairs and services, it was found to be not significant which means that the respondents from the SUC's surveyed have the same responses to the issue at hand and can be implied that the implementation of the student affairs program and services in SUC's does not affect the degree of responsiveness of the respondents.

That insufficient budget allocation is the major problem in the implementation of the students' welfare and development programs and services. This implies that a lot of programs and activities are not yet provided and implemented or given to make its clientele appreciate the program and activities as reflected in the action plan.

As a result of exhaustive analysis, the researcher came up with the theory "Active Management for Institutional Transformation" (AMIT's Theory) which posits that for an educational institution to keep pace with the rapid technological changes and be true to itself, the planning and management of all its assets/resources should become a regular, potent and dynamic activity of the administration, the faculty and the staff with the active partnership of its highest governing body and the entire academic community.

Moreover, the rapidity of the institutional change that comes about as a result of internal and external forces will cause institutions to move toward relatively greater concern and adapt quickly to new situations.

\section{Recommendation}

The main thrust of the institution should be well delivered to its clientele on the components of student affairs and services as specified in the action plan. There should be a continuous assessment or evaluation in the implementation of the students' affairs services and programs to pinpoint their strengths and weaknesses so that remedial measures could be given immediately to students' needs. Student service providers should endeavor themselves to bond together as a potent and formidable organization with the end in view of having a uniformed implementation of CHED Memo No. 9 in all Higher Education Institutions.

Student affairs and services must be delivered in a manner that is smooth, meaningful, and integrated with the academic mission of the institution. These practices and resulting policies must be built upon sound principles and research, and carried out by partnering with the entire campus 
community. A follow-up study should be conducted with a wider scope and perspective in terms of respondents and objectives.

\section{References}

[1] Austin, TR., Lau, AR, Wood Brooks, C. (2012). Assessing students' moral and spiritual growth at Catholic Liberal Arts Colleges: A collaborative grant-funded initiative. Journal of College and Character. 13 (4).

[2] Bloland, PA. (2009). Student personnel training for the chief student affairs officer: Essential or unnecessary?. NASPA Journal. 17 (2).

[3] Bobsworth, K. (2009). Major in Asian language and culture. UBC Calendar. 10.

[4] Bryson, J. M. (2008). Strategic planning for public and non-profit organizations: A guide to strengthening and sustaining organizational achievement. San Francisco, United States: JosseyBass Publishers, Inc.

[5] Buller, JL. (2002). The essential academic dean: A practical guide to college leadership. New Jersey, United States: Prentice Hall, Inc.

[6] Case, K, Fair, R (2007). Principles of economics. Upper Saddle River, New Jersey: Pearson Education.

[7] Castillon-Boiser, D. (2000). Strategies for teaching: A modular approach. First Edition. Manila: Rex Book Store, Inc.

[8] Chickering, AW, Reisser, L. (2003). Education and identity. Second Edition. San Francisco, California: Jossey-Bass Publishers, Inc.

[9] David, FP. (2005) Understanding and doing research: A handbook for beginners. Iloilo City, Philippines: Panorama Printing, Inc.

[10] Espedido, AB. (2001). The school administrators. The Modern Teacher. 32 (7).

[11] Evans, NJ, Forney, DS, DiBrito, F. (2008). Student development in college: Theory, research, and practice. San Francisco, California: Jossey-Bass Publishers, Inc.

[12] Keitel, R. (2008). A proposed model of higher education institution-Call center industry partnership. The Asia-Pacific Education Researcher. 17 (2).

[13] Martin, J. (2006). Organizational behavior and management. Third Edition. University of Hull.

[14] McPherson, M. S., Schapiro, M. O. (2002). The blurring line between merit and need in financial aid. Change. 34 (2).

[15] O’Donnelly, J. P. (2012). Fundamentals of management, Ninth Edition. Kenya University.

[16] Patterson, J. C. H. (2008). Counseling and guidance in school: A first course, Revised Edition. New York, United States: Hamper and Row Publishers.

[17] Rhatigan, JJ. (2010). The handbook of student affairs administration: The history and philosophy of student affairs, Revised Edition. San Francisco, California: Jossey-Bass Publishers, Inc.

[18] Robbins, SP. (2001). Organizational behavior, Ninth Edition. New Jersey: Prentice Hall, Inc.

[19] Smith, J. M. (2008). The evolution of sex. Massachusetts, United States: Cambridge University Press.

[20] Thurstone, L. L. (2000). The vectors of mind. Chicago: American Psychological Association, Inc.

[21] Torres, V, Jones, SR, Renn, KA. (2009) Identity development theories in student affairs: Origins, current status, and new approaches. Journal of College Student Development. Johns Hopkins University Press. 50 (6).

[22] Wilson, Everett K. (2001). Sociology: Rules, roles and relationships. Home, Illinois: The Dorsey Press.

*Corresponding author.

E-mail address: raa714@yahoo.com 